\title{
1: 157825530-157822115
}

National Cancer Institute

\section{Source}

National Cancer Institute. 1:157825530-157822115. NCI Thesaurus. Code C44970.

Physical location of USF1_Gene 